Executive Editor: Altieres de Oliveira Silva

Associate Editor: Manuel Portugal Ferreira, Ph.D.

Evaluation Process: Double Blind Review pelo SEER/OJS

\title{
POTENTIAL IMPACT OF CREATIVE INFUSION ON PERCEPTIONS AND BEHAVIORS OF VISITORS: THEORY AND EVIDENCE FROM TOURISM
}

\author{
1 SINEM KUNT \\ 2 BILGEHAN GÜLCAN
}

\begin{abstract}
This study aims to synthesize creative infusion with the theory of inoculation. It is sought to reveal the potential impact of this synthesis' application on the perceptions and behaviors of visitors. Relationships among variables are assessed using Solomon Four Group and Factorial Modeling based on experimental designs. The data are gathered from tourists $(n=451)$ at the Seven Churches sites (Ephesus, Smyrna, Pergamum, Sardis, Philadelphia, Thyatira and Laodicea) in Turkey. Model results indicate that perceived creative infusion has a significant impact on revisits and recommendations. This is the first study which examines the relationship between perception and behavior by synthesizing creative infusion with inoculation theory in the tourism literature. Furthermore, it is a new contribution to the tourism literature through its revealing that inoculation theory also works in synthesis with creative infusion in the field of destination marketing as previously shown in such fields as behavioral science, communication, marketing and social psychology.
\end{abstract}

Keywords: Inoculation theory. Creative infusion. Destination marketing. Tangible cultural heritage. Seven Churches.

Received on September 25th, 2020 Approved on December 23th, 2020 (c) (i) (8)

\section{(3) in in}

(APA)

KUNT, S., \& GÜLCAN, B. (2021). Potential impact of creative infusion on perceptions and behaviors of visitors: theory and evidence from tourism. International Journal of Professional Business Review, 6(1), 1-19. doi: http://dx.doi.org/10.26668/businessreview/2021.v6i1.198

\footnotetext{
1 Sinem Kunt is a PhD graduate from Tourism Management, Faculty of Tourism, Gazi University, Ankara, Turkey and continues her academic career at Çankırı Karatekin University, School of Ilgaz Tourism and Hotel Management, Department of Tourism Management. She does research in fields of Destination Marketing, Tangible Cultural Heritage Tourism, Seven Churches and Creative Infusion. Email: kuntsinem@gmail.com Orcid id: https://orcid.org/0000-0002-5342-4734

2 professor at the Department of Recreation Management in the Faculty of Tourism at Ankara Hacı Bayram Veli University, Turkey. He received the PhD degree in education of tourism and hotel management and the MSc degree in tourism and hotel management from Gazi University, Turkey, and has specialized in tourism marketing, tourism education, and cultural tourism. He has conducted and participated in several international and national projects, especially in tourism education and tourism development in Turkey and Kyrgyzstan. Email: bilgehan.gulcan@hbv.edu.tr
}

Intern. Journal of Profess. Bus. Review; São Paulo V.6 N.1 2021, pp. 1-19, Jan/Dec.2021 


\title{
IMPACTO POTENCIAL DE LA INFUSIÓN CREATIVA EN LAS PERCEPCIONES Y COMPORTAMIENTOS DE LOS VISITANTES: TEORÍA Y EVIDENCIA DEL TURISMO
}

\begin{abstract}
RESUMEN
Este estudio tiene como objetivo sintetizar la infusión creativa con la teoría de la inoculación. Se busca revelar el impacto potencial de la aplicación de esta síntesis en las percepciones y comportamientos de los visitantes. Las relaciones entre las variables se evalúan utilizando el modelo de cuatro grupos de Solomon y el modelo factorial basado en diseños experimentales. Los datos se recopilan de turistas $(n=451)$ en los sitios de las Siete Iglesias (Éfeso, Esmirna, Pérgamo, Sardis, Filadelfia, Tiatira y Laodicea) en Turquía. Los resultados del modelo indican que la infusión creativa percibida tiene un impacto significativo en las revisiones y recomendaciones. Este es el primer estudio que examina la relación entre percepción y comportamiento sintetizando la infusión creativa con la teoría de la inoculación en la literatura turística. Además, es una nueva contribución a la literatura turística al revelar que la teoría de la inoculación también funciona en síntesis con la infusión creativa en el campo del marketing de destinos, como se mostró anteriormente en campos como las ciencias del comportamiento, la comunicación, el marketing y la psicología social.
\end{abstract}

Palabras clave: Teoría de la inoculación. Infusión creativa. Marketing de destino. Patrimonio cultural tangible. Siete iglesias.

\section{IMPACTO POTENCIAL DE LA INFUSIÓN CREATIVA EN LAS PERCEPCIONES Y COMPORTAMIENTOS DE LOS VISITANTES: TEORÍA Y EVIDENCIA DEL TURISMO}

\section{RESUMEN}

Este estudio tiene como objetivo sintetizar la infusión creativa con la teoría de la inoculación. Se busca revelar el impacto potencial de la aplicación de esta síntesis en las percepciones y comportamientos de los visitantes. Las relaciones entre las variables se evalúan utilizando el modelo de cuatro grupos de Solomon y el modelo factorial basado en diseños experimentales. Los datos se recopilan de turistas $(n=451)$ en los sitios de las Siete Iglesias (Éfeso, Esmirna, Pérgamo, Sardis, Filadelfia, Tiatira y Laodicea) en Turquía. Los resultados del modelo indican que la infusión creativa percibida tiene un impacto significativo en las revisiones y recomendaciones. Este es el primer estudio que examina la relación entre percepción y comportamiento sintetizando la infusión creativa con la teoría de la inoculación en la literatura turística. Además, es una nueva contribución a la literatura turística al revelar que la teoría de la inoculación también funciona en síntesis con la infusión creativa en el campo del marketing de destinos, como se mostró anteriormente en campos como las ciencias del comportamiento, la comunicación, el marketing y la psicología social.

Palabras clave: Teoría de la inoculación; Infusión creativa; Marketing de destino; Patrimonio cultural tangible; Siete iglesias.

\section{INTRODUCTION}


With today's increasing competition among destinations, destination marketers need to be creative to be one step ahead of their competitors and to predict opportunities and threats on the horizon. At this point, creativity is used extensively in the field of marketing and there are different techniques for conveying creativity (Mclntyre, 1993; Andrew, Smith \& 1996; Slater, Hult \& Olson, 2010). One of these techniques is infusion (Hagtvedt \& Patrick, 2008; Wood, Thorne \& Butte, 2017). In particular, infusion creates behavioral change (Bither, Dolich \& Nell, 1971; Lessne \& Didow, 1987; Mikolon, Quaiser \& Wieseke, 2015), and it is understood that this is a factor in destination marketing that may affect the intention to visit and recommend. On the other hand, the name of one stage of strategic destination marketing planning is creative infusion (Edgell, Ruf \& Agarwal, 2000). This research focuses on creative infusion, which deals with the concepts of creativity and infusion.

This study was conducted on the Seven Churches, which are in the Bible's Revelation (The Bible, 2010). These churches are tangible cultural heritage and are located in the Aegean Region of Turkey. This research was conducted on the basis of experiments. Three types of data collection method were used: Delphi, Observation and Questionnaire. In order to observe whether creative infusion messages cause a change to the perceptions and behaviors of visitors, the visitors were first asked to answer questions regarding their current perception and behavior towards the site, and then they were asked to respond, regarding their perceptions and behavior, to expressions of creative infusion. The following research question was formulated: Can creative infusion perception have an inoculating effect on the behavior of visitors?

The purpose of this study to reveal the potential impact on visitors' perceptions and behaviors of synthesizing creative infusion with the theory of inoculation.

\section{Theoretical background and research hypotheses Inoculation theory}

After the Second World War, speculative discussions about whether persuasive communication is more effective when only arguments or propaganda supporting the position of the communicator are presented, or whether the persuasive effects are greater when discussions on opposing arguments have been brought to the agenda and then refuted. Hovland, Lumsdaine and Sheffield (1949) experimentally proved that the former is not the case. According to the authors, double-sided messages are clearly more effective in making beliefs or attitudes more resistant than single-sided messages (cited by Lumsdaine \& Janis, 1953, p. 312). Lumsdaine and Janis (1953) conducted a continuation of the study above. According to the authors, a counter attack message should be prepared to see the difference between the effects of single and double sided messages. In this way, it was thought that the difference of effect between the two types of message could be exposed. According to the results of the research, unilateral and bilateral messages had similar effects on subjects who were not exposed to the counter attack message. However, a significant difference was detected in subjects who were exposed to the counter attack. As a result of the research, "two-sided" defenses were deemed more efficacious than the "one-sided" in conferring resistance to persuasion (Lumsdaine \& Janis, 1953, p. 315). This result was similar to the research results of 'Hovland et al. (1949)'. Doublesided messages are more effective against persuasive efforts than single-sided messages.

McGuire (1961a, p. 184) interpreted the scenario of resisting persuasion efforts with a different approach. His inoculation theory is analagous to the biological immunization process against certain types of diseases. According to McGuire (1964, p. 200), people are made resistant to an attacking virus by pre-exposure to a weakened dose of the virus which stimulates their defenses to overcome any massive viral attack. According to McGuire (1961a), inoculation messages first threaten the recipient with an attack on their current attitudes or beliefs, then motivate the recipient to defend their current belief or attitude against attacks or rebuttal messages. According to McGuire (1961b, p. 326), on the basis of inoculation, there is an element of selective perception. Recipients first notice messages in line with their current attitudes and beliefs and do not perceive counter-messages, ignoring them.

In the following years, McGuire (1961a, 1961b) and McGuire and Papageorgis $(1961,1962)$ retested inoclation theory with psychological experiments. McGuire (1964) thought it to be effective due to a triggering effect of inoculation. In short, it was 
concluded that triggering information given to the recipient has an inoculation effect on the recipient. Since its inception, Inoculation Theory has evolved and is still used in a wide variety of disciplines including in marketing (Bither, Dolich \& Nell, 1971; Lessne \& Didow, 1987; Mikolon, Quaiser \& Wieseke, 2015), communication (Briggs \& Harwood, 1983; Godbold \& Pfau, 2000; Haigh \& Pfau, 2006; 'Hovland et al. (1949)'; 'Pfau et al. (1997)', social psychology (McGuire, 1961a, 1961b), and behavioral science 'Thompson et al. (2010)' as a growing and mature theory.

\section{Creative infusion}

Creative infusion is a concept that Edgell, Ruf \& Agarwal put forward in their articles in 2000 as a step in Strategic Destination Marketing Planning. According to the authors, the concept can be used in Strategic Destination Marketing Planning to combine and synthesize the creative practices and the outsidethe-box, innovative and visionary ideas of the stakeholder team (Client's Executive), thereby laying the foundations that will serve as a basis for the organization's branding, image development and positioning work in the next step. However, the authors did not explain the details with the analyses or methods that should be undertaken at the relevant step.

The concept has not been contemplated in the disciplines of marketing and tourism in the period since (Beirman, 2003; Metaxas, 2009; Muhcina \& Liviu, 2012; Soteriades \& Avgeli, 2007; Tsiotsou \& Goldsmith, 2012; Wickramasinghe \& Takano, 2009). On the other hand, the authors did not mention the concept of "creative infusion" in their other works (Edgell, 2006). For this reason, there is a gap in the measurement/analysis methods to be used in studies on the creative infusion step of Strategic Destination Marketing Planning. The concept of "infusion" can be seen to have been dealt with in many disciplines, such as education (McGuinnes, 2005), communication (Macharia \& Pelser, 2014), social psychology (Forgas, 1994), health (Emekli, 2003) and marketing (Basu \& Wang, 2009; Kim, Ko \& Li, 2012).

In short, in this research, the concept of "infusion" is used in the consideration of this step. Working within tourism marketing, we intend to achieve our desired result by using Inoculation Theory in the form of a "Customer Inoculation" regarding the cultural heritage visitor's intent to revisit and recommend. Therefore, the aim of the study is not to carry out Strategic Destination Marketing Planning but to reveal the possible effect of creative infusion on the visitor's intent to revisit and recommend by using Inoculation Theory. The infusion is to be creatively designed with the Delphi method, enabling creative ideas to be collected. The results that will thereby arise can be used as a method for analyzing the step that 'Edgell et al. (2000)' recommended but did not explain in sufficient detail. This method is thought to be beneficial to destination marketers in the developing of proactive strategies and in the measuring of the the impact of the developed strategies. In addition, this method shall serve as a practical road map that can be applied to any destination or cultural asset by following the steps specified in this research.

\section{Synthesis of creative infusion and inoculation theory in destination marketing}

The theory has been applied in various disciplines (behavioral science, communication, marketing, social psychology) since the Second World War, developing and evolving in parallel with social structures and technological developments. Based on the literature review, inoculation theory has not been used in studies in which the main subject was tourism. Every day, consumers' travel decisions are affected by economic, technological, social and political changes. As in other sectors, the tourism industry is also experiencing competition intensively. Destinations are defined as mixes of tourism products that offer integrated experiences to consumers. Destinations are considered well-defined geographical areas, such as country, island or city. Nevertheless, the destination is seen as a "perceptual concept that can be interpreted subjectively according to the travel routes of the consumers, their cultural histories, visit objectives, educational levels and past experiences" (Buhalis, 2000, p. 97). "Marketing of countries, regions and continents as destinations is emerging as an activity developing in recent years". It is believed that destinations which cannot ensure their sustainable development, cannot diversify their attractions, cannot use their resources in the best way, and cannot perform "new and creative marketing activities" will lose their share in the international market in the future (Özdemir, 2008, p. 6-12). So, destinations have to implement 


\section{$\equiv$ JIPBR eview}

Potential impact of creative infusion on perceptions and behaviors of visitors: theory and evidence from tourism

new and creative activities or use strategies in order to set themselves apart from their competitors. Moreover, both the media and consumer discourses or comments shared on social media platforms can affect travel decisions. Inoculation Theory is thought to be an effective strategy that can be used in tourism in protecting consumers and making positive attitudes resistant against these negative messages or propaganda. Creative infusion gains importance at this point. 'Edgell et al. (2000)' proposed a new approach to strategic marketing planning for the tourism industry. It can be seen in Figure 1.

Figure 1: Strategic marketing planning stages for the tourism industry

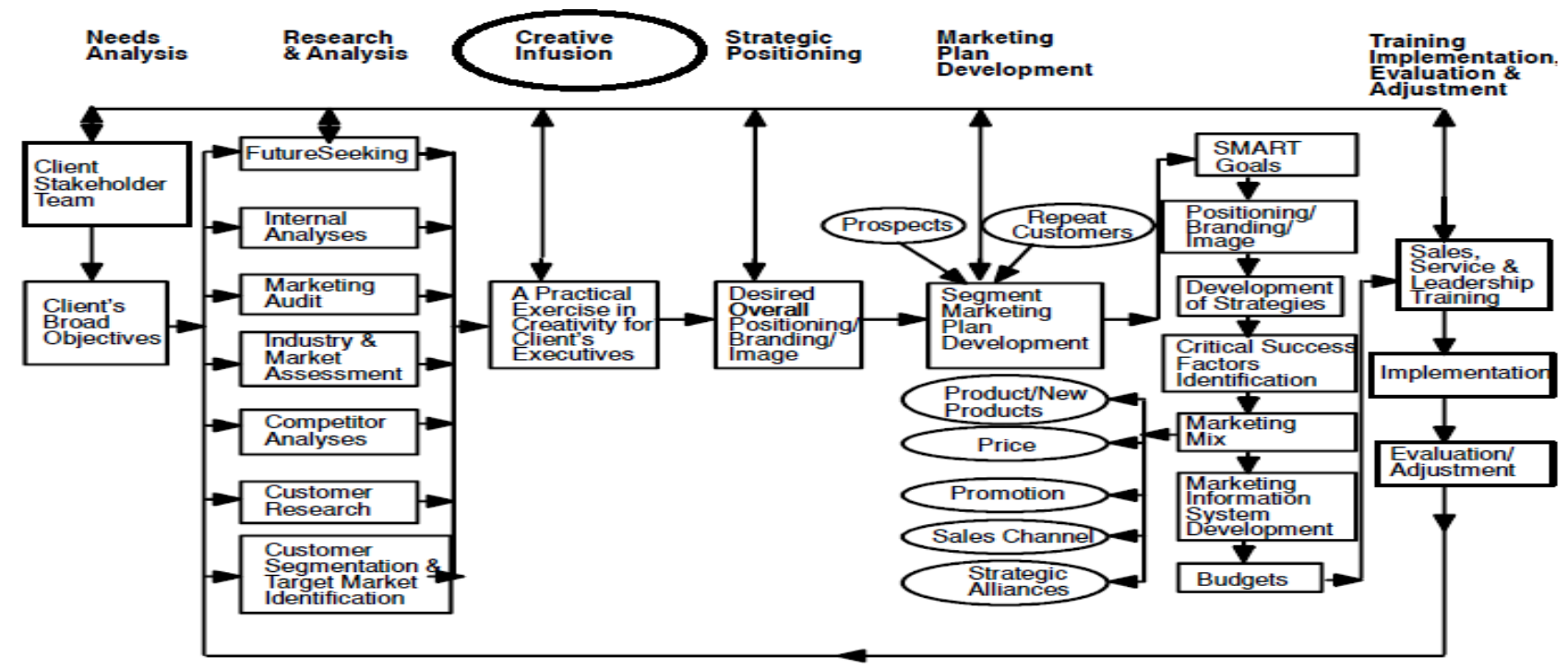

Source: Edgell, Ruf \& Agarwal, 2000

When the model is examined, it can be said that almost every step is subject to different fields of tourism outside of the creative infusion that they investigated. However, as a result of the literature review, the third step of the model, Creative Infusion, is seen not to have been included in the strategic destination marketing plans and was not tested (Rovelstad \& Blazer, 1983; Gilbert, 1990; Heath \& Wall, 1991; Chandra \& Menezes, 2001; Beirman, 2003; Soteriades \& Avgeli, 2007; Metaxas, 2009; Wickramasinghe \& Takano, 2009; Muhcina \& Liviu, 2012; Tsiotsou \& Goldsmith, 2012). 'Edgell et al. (2000)' do not mention any steps in the creative infusion.

The step generally suggests that after evaluating the results of research and analysis, the stakeholder team will come together to make applications that will reveal their creativity and see outside of the box. According to the authors, this step means real research that uses "creativity, innovation and imaginative ideas" which are the factors that will distinguish their destinations from those of competitors. On the other hand, the study does not provide any information about how this step should be designed or for its measurement. This is considered to constitute a gap in the literature, and it is anticipated that the design and measurement of this step will make an important contribution to the tourism literature.

In this study, it was tried to elucidate the concept on the basis of the word "infusion". Infusion is not a new word; it is accepted that its origin dates back to the Roman Period. The Sanctuary of Asklepion Bergama, known to be from the 4th century BC, in Turkey was "the world's first treatment center with infusion" (Emekli, 2003, p. 41). Infusion, a concept that "affects cognitive condition" (Fiedler, 1991, p. 22), is of Arabic origin. Infusion is seen that it is a word emphasized in scientific studies. Forgas (1994) conducted research on the factors affecting decisions and stated that the existing theoretical frameworks are insufficient in identifying the factors affecting decisions in experimental research. This situation directly affected the development of the "infusion effect" model. According to Johnston \& Bate (2013, p. 150), infusion provides a new perspective and way 
of thinking in achieving both individual and organizational goals.

Consequently, when consumers have to choose among alternatives, their preferences and attitudes can change with the infusion of new information (Chen, 1998, p. 6). As a result, it is understood that creative infusion is an unconscious process that allows the individual to infuse an emotion and thought created in new, different or creative content, and to enable the individual to act in line with the infused emotion and thought. Based on the above information, it was tried to synthesize the creative infusion with the theory of inoculation based on having similar aspects.

- Creative infusion is a step in strategic marketing planning 'Edgell et al. (2000)'. In other words, infusion is a "strategy" (Butterworth, O'Connor, Stevens \& Lord, 2005, p. 4). Inoculating messages are also considered a "message strategy" (Compton \& Ivanov, 2013, p. 253; Ivanov, Parker, Miller \& Pfau, 2012; Pfau \& Burgoon, 1988; Pfau, Haigh, Sims \& Wigley, 2007)

- Creative infusion uses imaginative ideas 'Edgell et al.(2000)'. Inoculating messages also use fantasy ideas (Compton, 2016; Wan \& Pfau, 2004).

- Creative infusion is to inoculate a feeling or thought into a person. Emotions 'Ivanov et al. (2012)' and thoughts (Lumsdaine \& Janis, 1953) are inoculated into the subjects with the inoculating messages.

- The aim of the creative infusion is to activate a thought, emotion or practice in the person. Inoculating messages also trigger or motivate the recipient to take action (Ivanov, Parker \& Compton, 2011; McGuire, 1964).

- Creative messages affect the cognitive condition (Fiedler, 1991). Cognitive, emotional and behavioral aspects can be seen in the effects of an inoculating message (Lessne \& Didow, 1987).

- Creative infusion is not a spontaneous event, it must be conveyed by an external source. Inoculating messages should also be conveyed to recipients from an external source (McGuire, 1961b).

- Inoculating messages are shown among cognitive models (Berger, Roloff \& Ewoldsen, 2010). Creative infusion also affects the cognitive condition (Fiedler, 1991).
- One of the aims of inoculation is to motivate the individual to a behavior (Compton \& Pfau, 2004; Compton \& Pfau, 2009; Godbod \& Pfau, 2000; Haigh \& Pfau, 2006; Lessne \& Didow, 1987; Pfau \& Burgoon, 1988; 'Thompson \& et al. (2010)'. One of the aims of creative infusion is to turn the message into action.

- Inoculating messages include supportive, refutational and novel messages (McGuire, 1961a, p.188). In this context, the creative infusion is similar to the novel message.

- Creative infusion is effective in achieving individual and organizational goals (Edgell et al., 2000, p. 117; Johnston \& Bate, 2013). It is observed that personal and organizational goals are achieved in inoculation theory (Haigh \& Pfau, 2006).

- Creative infusion can affect a person's decisions (Chen, 1998). Inoculation theory can affect both present 'Kim et al. (2012)' and potential decisions 'Thompson et al. (2010)'; Wan \& Pfau, 2004).

- There are similarities in the relationship between creative infusion and inoculation in terms of affecting "behavior" in the fields of psychology and marketing 'Kim et al. (2012)'; 'Thompson et al. (2010)'.

- Creative infusion and inoculation theory have similar characteristics (inoculating of novel messages) in cultural anthropology (Lalone, 2005; Briggs \& Harwood, 1983).

\section{Research hypotheses}

Based on the literature review, it has been proven that inoculating messages affect behavior and are used in many disciplines. In addition, it has been observed that creative infusion and inoculation have many similar aspects. If so, can the perception of creative infusion have an inoculating effect and cause any change to visitors' behavior? Accordingly with the research question expressed, the central research hypotheses of the current research are that:

$\mathrm{H}_{1}$ - There is a significant relationship between the perception of creative infusion and the possibility of the potential behavior; and

$\mathrm{H}_{2}$ - Creative Infusion perception affects the possibility of potential behavior. 


\section{\#JPBR eview}

Potential impact of creative infusion on perceptions and behaviors of visitors: theory and evidence from tourism

\section{METHODOLOGY}

It is aimed to reveal the relationship between perception and behavior in order to respond to the research question and hypotheses. The research follows an experimental model. Experimental models have also been used in inoculation theory studies (McGuire, 1961a, 1961b, 1964; McGuire \& Papageorgis, 1961, 1962). Multiple data collection techniques were used in the research (Delphi, observation, questionnaire). Confirming the data obtained by Delphi method through observation and measuring it by questionnnaire means the method of this research can be defined as data triangulation (Wilson, 2014). The methods used in this study are summarized below (see more Kunt, 2019, p. 109140.)

\section{Data collection procedures}

\section{The first data collection technique - Delphi}

The Delphi technique was developed in the 1950s by two researchers, Olaf Helmer \& Norman Dalkey (Dalkey \& Hermer, 1963). The aim of this technique is to make predictions about the future, to reveal expert opinions and to compromise. The Delphi technique was preferred to obtain creative infusion messages and the following research problem was prepared for the Seven Churches, which are the application area of the research:

The Seven Churches (Ephesus, Smyrna, Pergamum, Thyatira, Sardis, Philadelphia, Laodicea) are in what is today Turkey's western Aegean Region (called Asia Minor in the Roman Period). They are today within the provincial borders of Izmir (Konak, Bergama, Selçuk), Denizli (Pamukkale) and Manisa (Alaşehir, Akhisar, Salihli). They are sacred destinations both in Christian theology and for religious tourism (Kunt \& Gülcan, 2017; Küçük, 2014). These churches are evaluated as being among the first established in the Early Christian Period (Küçük, 2013; Ramsey, 1904; Öter \& Çetinkaya, 2016; Wilson, 2010). Despite being an important cultural asset in Turkey, the Seven Churches were found to have limited visitor demand. There are also some speculations about the location of the Seven Churches in the West (Seven Churches Documentary, 2014). For example, it has been claimed that the Seven Churches may be in Jerusalem, Africa and America. Due to the absence of brand, image and positioning elements that promote the Seven Churches and differentiate them from other cultural assets, it is thought that there is incomplete and incorrect information about the Seven Churches (Kunt \& Gülcan, 2017). Therefore, research questions are expressed as follows:

"With which visual symbol or emblem can Seven Churches be introduced?"

"What slogan should be designed for the Seven Churches?"

"What kind of events should be organized in the places where the Churches are located in order to ensure that the visitors to the Seven Churches have an unforgettable experience during the visit?"

Experts were decided upon to answer the above research questions. In the selection of the experts, it was considered that they must have knowledge about the Seven Churches. Therefore, the experts were historians of religions, art history and archeology, guides, the travel agency organizing the Seven Churches tour, the Seven Churches Research Center, the Provincial Culture and Tourism Directorates (Denizli, İzmir, Manisa), Denizli Museum Directorate, the Tourism Advisory Office (Izmir \& Bergama) and a destination brand management specialist.

The Delphi process was completed between 201710-13 and 2017-12-28 (77 days), with 18 volunteer experts and with the help of online surveys in three rounds.

As a result of Delphi, a total of 5 creative infusion messages -1 emblem, 1 slogan and 3 events - were explored.

\section{Second data collection technique - Observation}

The purpose of the observation is to control the presence or absence of 5 creative infusion messages explored with Delphi technique, to determine the necessary physical evidence used in the promotion or awareness of the Seven Churches and to understand whether the questionnaire questions are compatible with the aim of the research.

Each of the Seven Churches was observed on site, between 2018-07-01 and 2018-07-07, through an observation form designed by the authors.

According to the on-site observation findings, it was determined that any of the 5 creative infusion messages obtained by Delphi technique were not 
included in the study area. In addition, it has been observed that the statements of the questionnaire comply with the objectives of the research and can be answered.

\section{The third data collection technique - Questionnaire}

Two different scales were used in the research. Firstly, Poria, Butler \& Airey's (2003) set of statements was adopted, originally used to measure the perception and behavior of visitors to the Wailing Wall. Secondly, the 5 creative messages obtained with the Delphi technique were adapted to fit the first scale in the form of a 5-point Likert Scale (1 = Strongly Disagree, 5 = Strongly Agree). A pilot study was carried out between 2018-06-07 and 2018-07-07. As a result of the pilot study, it was observed that two of the 5 messages (emblem and slogan) did not fit the purpose of the research. Respondents searched for emblems and slogans using a variety of communication tools, they asked friends or left the question unanswered. Therefore, it was concluded that these messages should be asked about differently. These messages were included in the questionnaire form as two questions that were structured so as not to depart from the purpose of the research.

Since the 3 event-based creative messages have not been designed yet, the messages have been transformed into hypothetical scenarios. Hypothetical scenarios were used in the inoculation theory (Wan \& Pfau, 2004).

The three messages in the form of events were turned into hypothetical scenarios as follows:
- Imagine that modern museum technologies are used to tell the history and stories, and about the iconic objects, events and people depicted in the stories, accompanied by holography. Answer the following statements about it.

- Imagine that an international conference on the Seven Churches in Turkey was organized. Answer the following statements about it.

- Imagine that replicas are being built that can be entered in relation to the Seven Churches. Answer the following statements about them.

As a result of the pilot study, it was seen that no problem was encountered in understanding and responding to the creative infusion messages regarding the events. On the other hand, due to limitations in understanding and responding to 2 message types (the emblems and slogans), the research was shaped around 3 messages (simulation, conference, replicas). The three creative messages were infused in the statements of the first scale. Statements in the first scale 'Poria et al. ( 2003)' - " ...visiting contributed to your education, ...felt that part of your own heritage was displayed", etc. - were adapted to the creative infusion (experimental) messages. For example, "watching the holography about the Seven Churches may contribute to your education, cause you to feel that some of your own heritage was displayed", etc.

\section{The research model}

The current research has been tested on two different models. The first is the Factorial model and the second is the Solomon Four Group Model.

Figure 2. Factorial model of the research

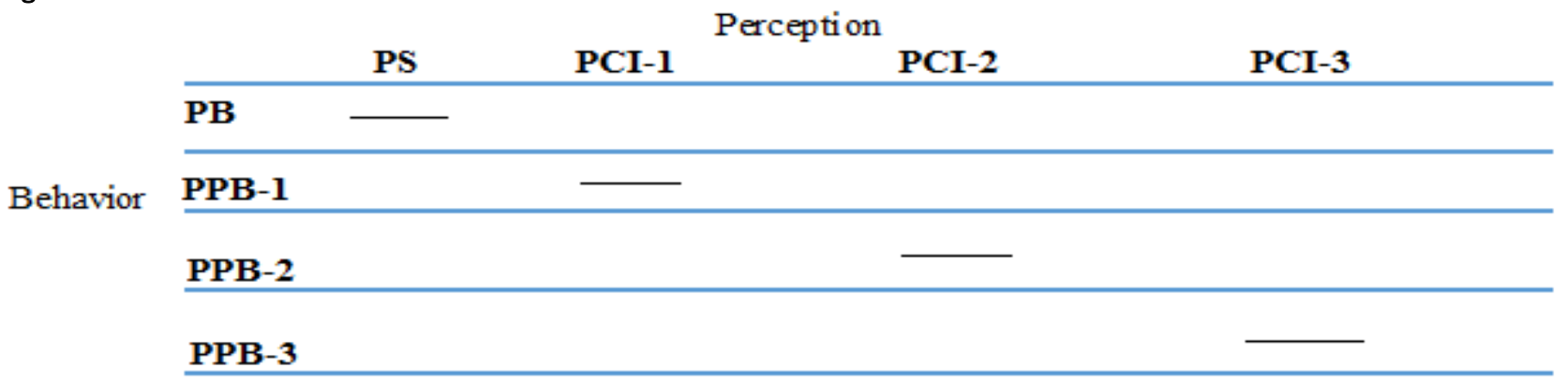

PS: Perception of Site PCl-1: Perception of Creative Infusion 1 PCl-2: Perception of Creative Infusion 2 PCl-3: Perception of Creative Infusion 3 PB: Potential Behavior PPB-1: Probability of Potential Behavior 1 PPB-2: Probability of Potential Behavior 2 PPB-3: Probability of Potential Behavior 3 


\section{$= \pm$ JPBR eview}

Potential impact of creative infusion on perceptions and behaviors of visitors: theory and evidence from tourism

The first model used in this research is the multivariable factorial model (figure 2). Factorial models have an increasingly widespread application area (Karasar, 2014, p. 95). It is attempted to test the effects of multiple independent variables (perception of visit, perception of creative infusion) on the dependent variable (potential behavior, probability of potential) together. In other words, an answer is sought to the question of which perception is more effective for which behavior. In the model, both the perception and the behavior variables are considered as scores out of four (four levels). The written expression of the model is " $4 \mathrm{X} 4$ factorial model".

Variables are separated by a cross $(X)$; the numbers show the number of levels within each variable type. The number " 4 " in the model represents the perception variable (visit, creative infusion) and the other number " 4 " represents the behavior (potential, probability of potential) variable. In summary, this model represents a multivariate trial model.

The second model used in the research is the Solomon Four Group Model. This model is preferred because it is the strongest trial model and protects internal and external validity together (Karasar, 2014, p. 99). It is aimed to reveal in detail whether creative infusion messages are effective or not on behavior. Below, all 3 creative infusion messages ( 3 scenarios) are modeled separately (figure 3 , figure 4 , figure 5 ). Descriptions of the abbreviations used in the models are given below:

- G: Group

- R: Randomness

- X: Independent Variable

- O: Observatio

Figure 3: First Creative Infusion Message (CIM 1-Simulation) Experimental Design

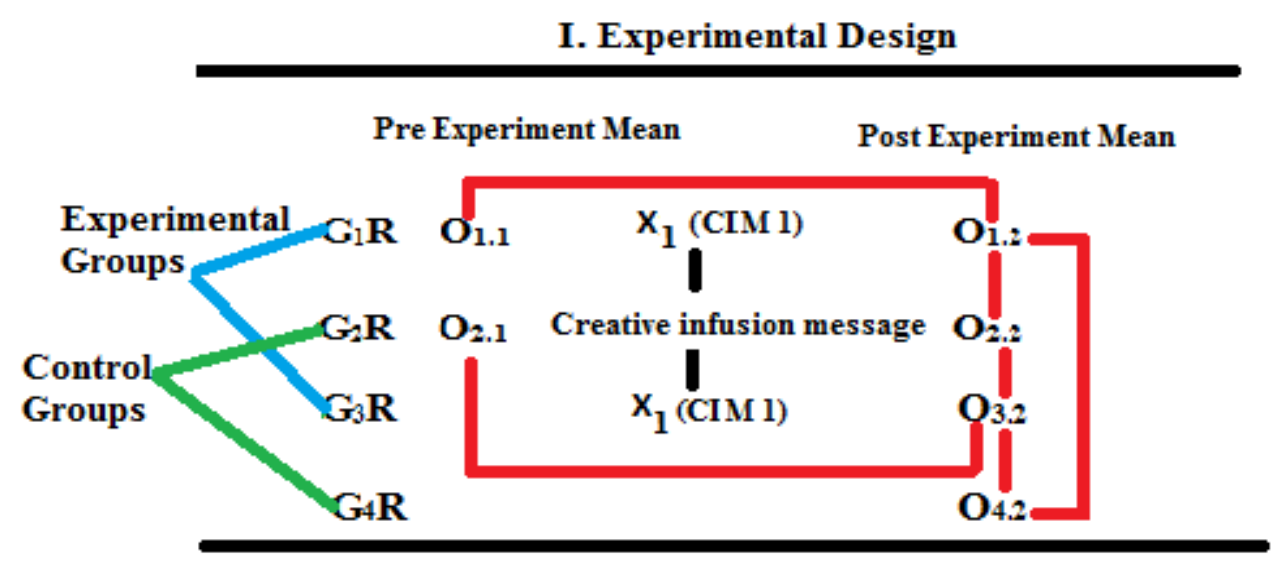

Figure 4: Second Creative Infusion Message (CIM 2-Conference) Experimental Design

\section{Experimental Design}

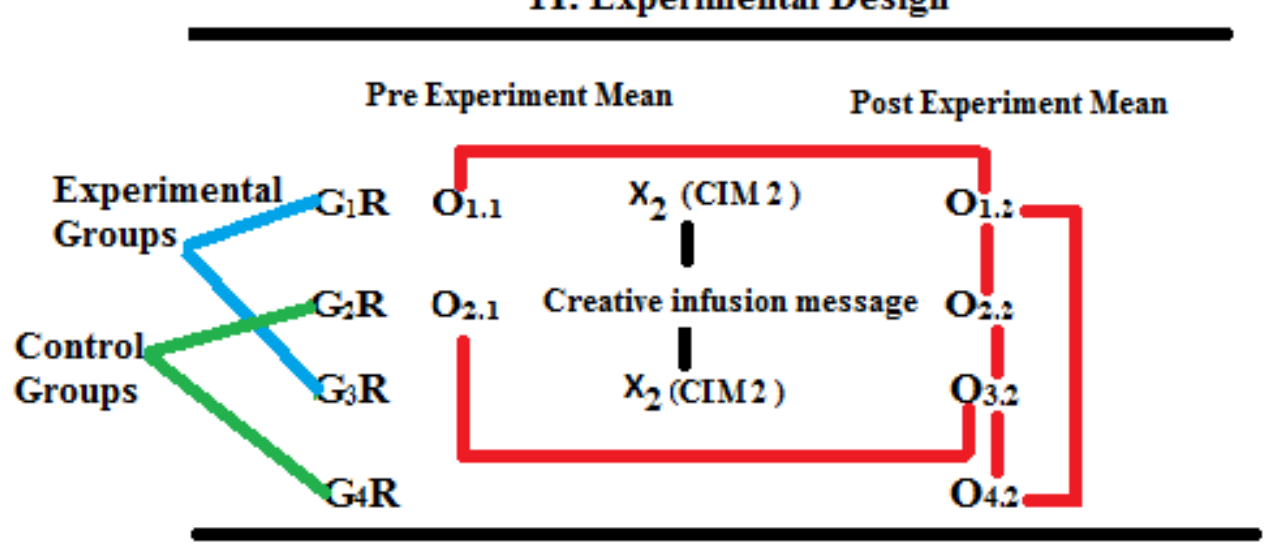


Figure 5: Third Creative Infusion Message (CIM 3-Replicas) Experimental Design

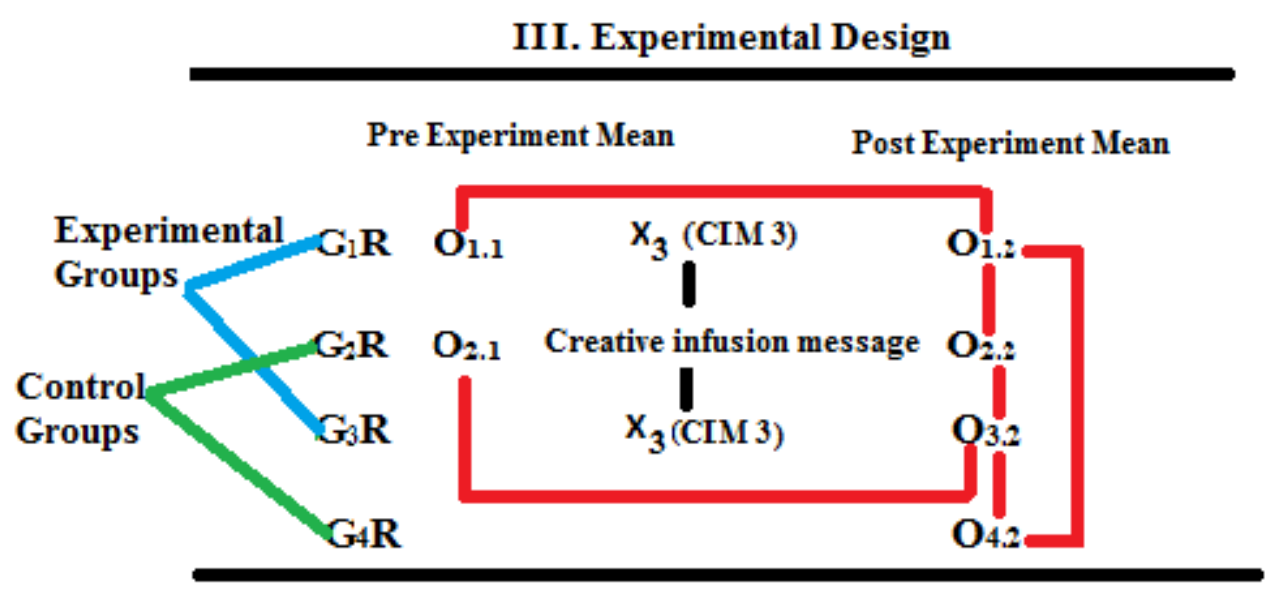

Six comparisons were made to observe the mean of the potential behavioral probabilities of subjects pre experiment (without receiving the creative infusion message) and post experiment (after receiving the creative infusion message). The six comparisons were applied separately for all three situations. The formal expressions of the comparisons made for the cases are shown in figures 3,4 and 5 . The fact that the results are in the form $\mathrm{O}_{1.2}>\mathrm{O}_{1.1} ; \mathrm{O}_{1.2}>\mathrm{O}_{2.2} ; \mathrm{O}_{3.2}>\mathrm{O}_{4.2} ; \mathrm{O}_{3.2}>\mathrm{O}_{2.1} ; \mathrm{O}_{3.2}>\mathrm{O}_{2.2}$ and $\mathrm{O}_{1.2}>\mathrm{O}_{4.2}$ is an indication that both the internal consistency and the validity of the comment on the effectiveness of $X$ (Creative Infusion) have increased (Karasar, 2014, p. 98).

The quantitative data obtained within the scope of the research were analyzed using the SPSS (Statistical Package for the Social Sciences) program.

\section{The Results of the quantitative data}

The whole sample was composed of 451 participants (44.8\% female and $55.2 \%$ male). With respect to age, it is understood that $26.4 \%$ of them were 25 years old and under, and $25.9 \%$ were 45 and older. With respect to education $64.5 \%$ of the sample, more than half, had earned a bachelors degree. Considering job status, it is understood that $23.3 \%$ were official and $16.6 \%$ were students. When nationality distributions are analyzed with respect to
In this research, rather than traditional single variable law, multi-variable law is taken into consideration in the interpretation of the trial models. In this research, the concept of "probabilistic relationship" can be mentioned in multiple causeeffect relationships. In this study, 451 valid questionnaires were collected. Simple random sampling method was used for sample selection. The questionnaires were collected from the volunteer visitors between 2018-07-15 and 2018-07-29 at the Seven Churches sites in the form of face-to-face surveys. The reason the surveys were collected in this way is that four of the Seven Churches (Pergamum, Ephesus, Laodicea, Sardis) are located in ancient cities, there are no guiding and informative signs, and only data were requested to be collected from the tourists visiting the sites where the Seven Churches are located.

regions, it is seen that $67.8 \%$ of them, constituting the majority, were of Europe, $16.2 \%$ were of Asia and the Pacific and $14.9 \%$ were of America. In terms of religion, $61 \%$ were Christians and $23.1 \%$ were Muslims. It is understood that of the Christians, 56.1\% were Catholic, 39.5\% were Protestant and $3.2 \%$ were Orthodox in terms of denomination. According to the results of the current research, the most visited churches among the Seven Churches are Ephesus with 49\% and Laodicea with 16.9\%. 


\section{$= \pm$ JPBR}

Potential impact of creative infusion on perceptions and behaviors of visitors: theory and evidence from tourism

Figure 6. Findings of the Factorial Model tested by Spearman's rho Correlation Analysis

\begin{tabular}{lllcl} 
& \multicolumn{4}{c}{ Perception of Site and Creative Infusion $(\mathrm{n}=451)$} \\
Behavior & \multicolumn{1}{c}{ PS } & PCI-1 & PCI-2 & PCI-3 \\
\cline { 2 - 5 } & PPB-1 &, $593(* *)$ & & \\
\cline { 2 - 4 } & &, $679\left(^{* *}\right)$ & \\
& & &, $647\left(^{* *}\right)$ &, $741\left(^{* *}\right)$ \\
\hline
\end{tabular}

PS: Perception of Site PCl-1: Perception of Creative Infusion 1 PCl-2: Perception of Creative Infusion 2 PCl-3: Perception of Creative Infusion 3 PB: Potential Behavior PPB-1: Probability of Potential Behavior 1 PPB-2: Probability of Potential Behavior 2 PPB-3: Probability of Potential Behavior 3

** Correlation is significant at the 0.01 level (2-tailed)

It is stated in the tourism literature that there is a significant relationship between perception of site and potential behavior 'Poria et al. (2003)'. In this study, a significant relationship was found between site perception and behavior (figure 6) and the literature was supported. In addition, there was a relationship between creative infusion perception and potential behavior, and in this, new information was added to the tourism literature. Hypothesis $\mathrm{H}_{1}$ was supported. This finding is important. Many studies in the literature on inoculation theory have revealed inoculated perceptions to have caused behavioral changes (Compton \& Pfau, 2004, 2009; Golden \& Albert, 1987; Godbod \& Pfau, 2000; Haigh \& Pfau, 2006; 'Kim et al. (2012)'; Lessne \& Didow, 1987; Lin, 2005; Pfau \& Burgoon, 1988; 'Thompson et al. (2010)'. For the first time, this study has revealed that there is a significant relationship between creative infusion perception and potential behavior by synthesis with inoculation theory and by application in regard of tangible cultural heritage sites in the field of tourism. This finding shows that creative messages can be used as a potential strategy to change behavior in the field of tourism. Creative messages need to be synthesized with the theory of inoculation in order to anticipate future tourist behaviors and develop proactive strategies.

The findings proved that the theory also works in the field of tourism. The findings can be beneficially used by many destination marketers to provide behavioral change. If the hypothetical scenarios are put into practice, it is understood that, compared to with their current perceptions, visitors are more likely to visit or recommend the site. As a result, it is seen that the highest relationship between perception and behavior is with Perception of Creative Infusion 3 $(\mathrm{PCl}-3)$. It has been determined that there is a positive, high level and significant relationship between $\mathrm{PCl}-3$ and PPB-3 compared to between other perceptions ( $\mathrm{PS}, \mathrm{PCl}-1, \mathrm{PCl}-2$ ). In other words, as the $\mathrm{PCl}-3$ increases, the PPB-3 increases at a high level. This finding shows that if replicas related to the Seven Churches are built, the probability of visiting a site again and recommending it will increase. 
Figure 7. Findings of the Factorial Model tested by Regression Analysis

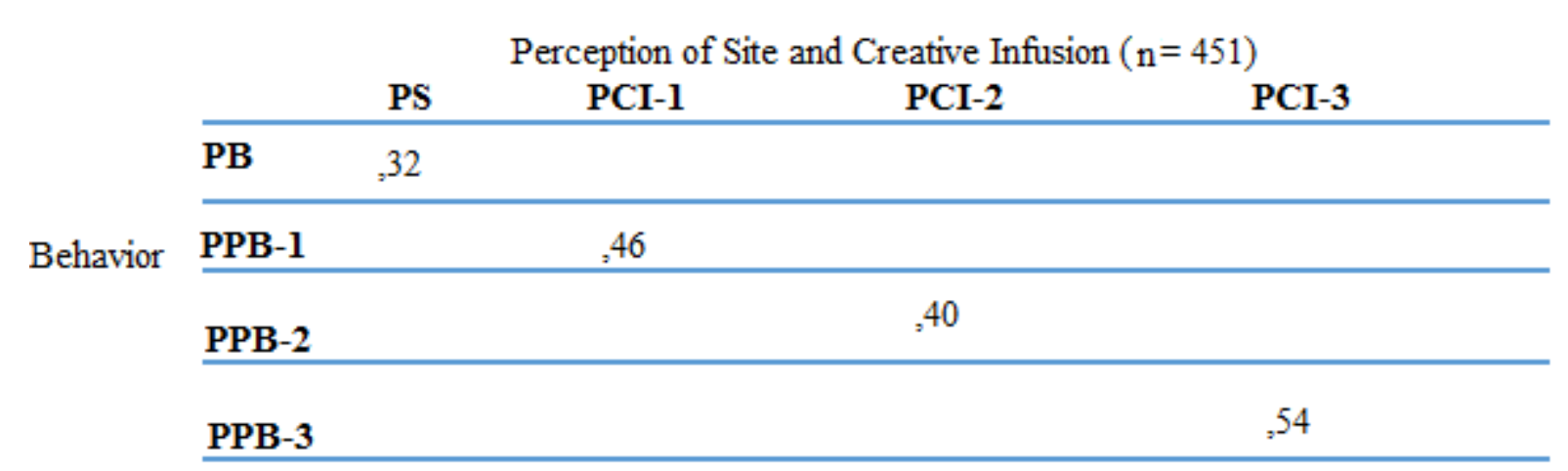

PS: Perception of Site PCl-1: Perception of Creative Infusion 1 PCl-2: Perception of Creative Infusion 2 PCl-3: Perception of Creative Infusion 3 PB: Potential Behavior PPB-1: Probability of Potential Behavior 1 PPB-2: Probability of Potential Behavior 2 PPB-3: Probability of Potential Behavior 3

When the effect of hypothetical scenarios on potential behavior probability is examined, it is seen that the third creative infusion perception (third scenario) has the highest effect with 54\% (see figure 7). Hypothesis $\mathrm{H}_{2}$ was also supported. Creative Infusion Perception 3 affects the possibility of potential behavior. It is known that inoculated perceptions have an effect on behavior in studies on inoculation theory (Compton \& Pfau, 2004, 2009; Golden \& Albert, 1987; Godbod \& Pfau, 2000; Haigh \& Pfau, 2006; 'Kim et al. (2012)'; 'Ivanov et al. (2011)'; Lessne \& Didow, 1987; Lin, 2005; Pfau \& Burgoon, 1988; 'Thompson et al. (2010)'. The findings supported the literature and also added new information in the field of tourism. The Creative
Infusion Perception affected the probability of potential behavior and the inoculation theory worked in the field of tourism. It was revealed in this current research that perceptions infused in the field of tourism have an effect on the probability of potential behavior as well as perceptions having an effect on potential behavior 'Poria et al. (2003)' .

It was seen in regression analysis that creative infusion messages were effective on behavior. However, it was aimed to reveal the effect of creative infusion on behavior in detail. For this, the all data set ( $n=451$ ) was randomly divided into four different groups according to the Solomon Four Group Model (see table 1). 


\section{=tJPBR}

Potential impact of creative infusion on perceptions and behaviors of visitors: theory and evidence from tourism

Table 1. Paired Samples Statistics (mean, number of samples, standard deviation and standard error mean of four randomly separated groups)

\begin{tabular}{|c|c|c|c|c|c|c|}
\hline Group* & & & Mean & $\mathrm{n}$ & Std. Deviation & $\begin{array}{l}\text { Std. Error } \\
\text { Mean }\end{array}$ \\
\hline \multirow{6}{*}{$\begin{array}{l}\text { First } \\
\text { Group } \\
\left(G_{1}\right)\end{array}$} & \multirow[t]{2}{*}{ Pair 1} & PB & 4,1460 & 113 & ,83568 & ,07861 \\
\hline & & PPB-1 & 4,1305 & 113 & 94201 & ,08862 \\
\hline & \multirow[t]{2}{*}{ Pair 2} & PB & 4,1460 & 113 & ,83568 & 07861 \\
\hline & & PPB-2 & 4,0442 & 113 & ,95445 & 08979 \\
\hline & \multirow[t]{2}{*}{ Pair 3} & PB & 4,1460 & 113 & ,83568 & 07861 \\
\hline & & PPB-3 & 3,9779 & 113 & 99247 & ,09336 \\
\hline \multirow{6}{*}{$\begin{array}{l}\text { Second } \\
\text { Group } \\
\left(G_{2}\right)\end{array}$} & \multirow[t]{2}{*}{ Pair 1} & PB & 4,2701 & 112 & ,84439 & 07979 \\
\hline & & PPB-1 & 4,1808 & 112 & 87714 & ,08288 \\
\hline & \multirow[t]{2}{*}{ Pair 2} & PB & 4,2701 & 112 & ,84439 & 07979, \\
\hline & & PPB-2 & 4,1496 & 112 & ,78733 & 07440 \\
\hline & \multirow[t]{2}{*}{ Pair 3} & PB & 4,2701 & 112 & ,84439 & 07979, \\
\hline & & PPB-3 & 4,1406 & 112 & ,83678 & 07907, \\
\hline \multirow{6}{*}{$\begin{array}{l}\text { Third } \\
\text { Group } \\
\left(\mathrm{G}_{3}\right)\end{array}$} & \multirow[t]{2}{*}{ Pair 1} & PB & 4,0686 & 113 & ,84002 & 07902 \\
\hline & & PPB-1 & 4,2898 & 113 & ,80565 & 07579 \\
\hline & \multirow[t]{2}{*}{ Pair 2} & PB & 4,0647 & 112 & ,84279 & 07964 \\
\hline & & PPB-2 & 4,1205 & 112 & 86796 & 08201 \\
\hline & \multirow[t]{2}{*}{ Pair 3} & PB & 4,0686 & 113 & ,84002 & ,07902 \\
\hline & & PPB-3 & 4,1792 & 113 & ,80558 & 07578 \\
\hline \multirow{6}{*}{$\begin{array}{l}\text { Fourth } \\
\text { Group } \\
\left(G_{4}\right)\end{array}$} & \multirow[t]{2}{*}{ Pair 1} & PB & 4,0619 & 113 & 91156 & ,08575 \\
\hline & & PPB-1 & 4,0708 & 113 & 89982 & ,08465 \\
\hline & \multirow[t]{2}{*}{ Pair 2} & PB & 4,0619 & 113 & 91156 & ,08575 \\
\hline & & PPB-2 & 4,0332 & 113 & ,84812 & 07978, \\
\hline & \multirow[t]{2}{*}{ Pair 3} & PB & 4,0619 & 113 & 91156 & ,08575 \\
\hline & & PPB-3 & 4,0730 & 113 & ,83831 & 07886 \\
\hline
\end{tabular}

The findings of the six comparisons on the first experimental design are presented in figure 8 . In four of the six comparisons, $X_{1}$ was effective. According to the findings regarding the first experiment group $\left(G_{1}\right)$, the mean post experiment $\left(\mathrm{O}_{1.2}\right)$ is not higher than the mean pre experiment $\left(\mathrm{O}_{1.1}\right)(4.13<4.16)$. This shows that $X_{1}$ is not effective. The mean of the first experimental group (G1) post experiment $\left(\mathrm{O}_{1.2}\right)$ is not higher than the mean of the first control group post experiment $\left(\mathrm{O}_{2.2}\right)(4.13<4.18)$. In this case, the effect of $X_{1}$ is not significant.

Figure 8. Findings about the First Creative Infusion Message (CIM 1)

\section{Experimental Design}

\begin{tabular}{lcc}
\hline Pre Experiment Mean (MI) & Post Experiment Mean (M2) \\
$\mathrm{G}_{1} \mathrm{R} 4,16$ & $\mathrm{X}_{1}$ (CIM 1) & 4,13 \\
$\mathrm{G}_{2} \mathrm{R} 4,27$ & & 4,18 \\
$\mathrm{G}_{3} \mathrm{R}$ & $\mathrm{X}_{1}$ (CIM 1) & 4,28 \\
$\mathrm{G}_{4} \mathrm{R}$ & & 4,07 \\
\hline
\end{tabular}

On the other hand, the mean of the second experiment group (G3) post experiment $\left(\mathrm{O}_{3.2}\right)$ is higher than the mean of the second control group
$\left(\mathrm{O}_{4.2}\right)$ post experiment $(4.28>4.07)$. In this case, the effect of $X_{1}$ is significant. The mean of the second experimental group post experiment is higher than 
the mean of the first control group $(4.28>4.27)$. In this case, it is said that $X_{1}$ has an effect on the probability of potential behavior.

Comparing the means of the second experimental group post experiment and the first control group post experiment, $X_{1}$ is seen to be effective (4.28 > 4.18). Finally, it is seen that the mean of the first experimental group post experiment is also effective as compared to the mean of the second control group $(4.13$ > 4.07). As a result, the model established for the first Creative Infusion Message is said to have an internal consistency of $66.7 \%$. The First Creative Infusion Message had a $67 \%$ impact on the probability of potential behavior.

Figure 9. Findings about the Second Creative Infusion Message (CIM 2)

\section{Experimental Design}

\begin{tabular}{lcc}
\multicolumn{2}{c}{ Pre Experiment Mean (MI) } & Post Experiment Mean (M2) \\
$G_{1} R \quad 4,14$ & $\mathrm{X}_{2}$ (CIM 2) & 4,04 \\
$G_{2} R \quad 4,27$ & & 4,14 \\
$G_{3} R$ & $\mathrm{X}_{2}$ (CIM 2) & 4,12 \\
$G_{4} R$ & & 4,03 \\
\hline
\end{tabular}

In the second experimental research case, comparison, $4.04<4.14 ; 4.04<4.14 ; 4.12>4.03$; comparisons have been made to determine the effect of Creative Infusion Message $2\left(X_{2}\right)$. Figure 9 shows the means of the subjects pre and post experiment. According to the results of the $4.12<4.27 ; 4.12<4.14$; and $4.04>4.03$. After a total of six comparisons, it is seen that $X_{2}$ is effective only in two comparisons. In this case, the model is said to have an internal consistency of $33.3 \%$.

Figure 10. Findings about the Third Creative Infusion Message (CIM 3)

\section{Experimental Design}

\begin{tabular}{|c|c|c|c|}
\hline \multicolumn{3}{|c|}{ Pre Experiment Mean (MI) } & \multirow{2}{*}{$\begin{array}{c}\text { Post Experiment Mean (M2) } \\
3,09\end{array}$} \\
\hline $\mathbf{G}_{1} \mathbf{R}$ & 4,14 & $\mathrm{X}_{3}$ (CIM 3) & \\
\hline $\mathbf{G}_{2} \mathbf{R}$ & 4,27 & & 4,14 \\
\hline $\mathbf{G}_{3} \mathbf{R}$ & & $\mathrm{X}_{3}$ (CIM 3) & 4,17 \\
\hline $\mathbf{G}_{4} \mathbf{R}$ & & & 4,07 \\
\hline
\end{tabular}

In the experimental model established with the Third Message of Creative Infusion, six comparisons were made $(3.9<4.14 ; 3.9>4.14 ; 4.17>4.07 ; 4.17<$ $4.27 ; 4.17>4.14 ; 3.9>4.07)$. As in the first

The paper is striving for a balance of theory and application. It is quite innovative and really strongly geared toward the methods associated with Inoculation Theory and Creative Infusion. The research is the first research that applies the theory of inoculation in the field of tourism and tries to test its effect on behavior. Although its empirical context experimental design, $X_{3}$ had an effect on the behavior in four of the six comparisons. This effect is said to be $66.7 \%$. The means of the groups pre and post experiment are shown in figure 10.

is a heritage context (the seven churches), the methods and conceptualization could be applied to any type of tourism in any area of tourism.

Three different experimental designs were tested with the Solomon Four Group Model for the perception of three types of creative infusion whose 


\section{\#JPBR eview}

Potential impact of creative infusion on perceptions and behaviors of visitors: theory and evidence from tourism

effect on potential behavior was to be tried. Six separate comparisons were made for all three experimental designs. While in the second experimental design the effectiveness of $X$ was observed in two of the six comparisons, in the first and third designs, the effectiveness of $X$ appeared in four comparisons. In other words, CIM1 and CIM3 are said to be more effective on the probability of the potential behavior of the subjects than with their current perceptions of site (PS). The potential behavior of the subjects based on their current perception changes after receiving the creative infusion messages.

These findings reveal that all three Creative Infusion Messages are effective and valid regarding

\section{CONCLUSIONS}

The applications of destination marketers differ in parallel with developments and changes in the world. On the other hand, the common goal of marketers is developing techniques that will affect purchasing behavior. Infusion, which is one of these techniques, gains importance especially in terms of its effect on behavior. Destination marketers' forecasting or testing of their strategies before realizing them prevents marketers from losing time, money and labor. At this point, based on a literature review, Creative Infusion, a step in strategic destination marketing planning, was explored. It was striven to synthesize this concept, which is considered a proactive strategy, with inoculation theory, and it was for the first time tried to use it for customer inoculation in tourism.

An answer was sought to the research question "Can the perception of creative infusion have an inoculating effect and cause any changes in visitors' behavior?".

As a result of the analyses, hyptheses $\mathrm{H}_{1}$ and $\mathrm{H}_{2}$ were supported. It was revealed that the Perception of Creative Infusion had an inoculating effect and caused a significant change in the behavior of the visitors. This result is usual for inoculation theory but an original finding for tourism. With this current research, inoculation theory has been tried and was effective in tourism for the first time. Provided that hypothetical scenarios are actualized, the visitors would intend to visit and recommend the Seven the probability of the potential behavior of the subjects. What differentiates messages is their impact level. The Solomon Four Group Model result based on the First Creative Infusion Message (CIM1) was $66.7 \%$, on the Second Creative Infusion Message (CIM2) was 33.3\%, and on the Third Creative Infusion Message (CIM3) was $66.7 \%$ with respect to the effect they had on the probability of the potential behavior of the subjects. There is a significant difference between all group means $(p<0.001)$. According to the model (Solomon Four Group) results used to deepen the interpretation of the effect of the Creative Infusion Messages, it can be said clearly that Creative Infusion makes a significant difference to behavior. Accordingly, the findings were supported by the results of correlation and regression analysis.

Churches more than according to their current perceptions of the site.

All three Creative Infusion Messages have an impact on the probability of the potential behavior of the subjects, but the effect levels differ. The scenario with the highest impact was the third scenario. The subjects would intend to visit and recommend the Seven Churches more in the future if symbolic replicas of the Seven Churches were made. In summary, it is recommended that the theoretical research findings be applied as soon as possible by Turkey's Culture and Tourism Ministry and the Directorates of the Provincial Culture and Tourism which operate in locations of the Seven Churches.

\section{Practical contributions of the research}

- The methods used in this study are thought to be beneficial to destination marketers in the developing of proactive strategies and in the measuring of the the impact of the developed strategies.

- Although the research's empirical context is a heritage context (the seven churches), the methods and conceptualization could be applied to any type of tourism in any area of tourism.

\section{Theoretical contributions of the research}

- This is the first study which examines the relationship between perception and behavior by 
synthesizing creative infusion with inoculation theory in the tourism literature.

- The research is a new contribution to the tourism literature through its revealing that inoculation theory also works in synthesis with

- creative infusion in the field of destination marketing as previously shown in such fields as behavioral science, communication, marketing and social psychology.

- If the hypothetical scenarios are put into practice, it is understood that, compared to with their

\section{REFERENCES}

Andrews, J., \& Smith, D. C. (1996). In search of the marketing imagination: Factors affecting the creativity of marketing programs for mature products. Journal of Marketing Research, 33(2), 174187.

Basu, A., \& Wang, J. (2009). The role of branding in public health campaigns. Journal of Communication Management, 13(1), 77-91. DOI:10.1108/13632540910931409

Beirman, D. (2003). Restoring tourism destinations in crisis: A strategic marketing approach. In B. Robyn and B. Richard (Eds.), Cauthe 2003: Riding the wave of tourism and hospitality research (pp. 1146-1150). Lismore, N.S.W: Southern Cross University.

Berger, C. R., Roloff, M. E., \& Ewoldsen, D. R. (Eds.). (2010). The handbook of communication science (pp. 210-211). United States of America: Sage Publications.

Bither, S. W., Dolich, I. J., \& Nell, E. B. (1971). The application of attitude Immunization techniques in marketing. Journal of Marketing Research, 8(1), 5661. DOI: 10.1177/002224377100800107

Buhalis, D. (2000). Marketing the competitive destination of the future. Tourism Management, 21(1), 97-116.

Butterworth, M., O'Connor, M., Stevens, J., \& Lord, C. (2005). Thinking through English. Cambridge: Chris Kington Publishing.

Briggs, N. E., \& Harwood, G. R. (1983). Furthering adjustment: An application of Inoculation Theory in an intercultural context. Eric Reproduction Service No.Ed225 221. current perceptions, visitors are more likely to visit or recommend the site.

- $\quad$ For the first time, this study has revealed that there is a significant relationship between creative infusion perception and potential behavior by synthesis with inoculation theory and by application in regard of tangible cultural heritage sites in the field of tourism.

- It is revealed in this current research that perceptions infused in the field of tourism have an effect on potential behavior of visitors

Chandra, S., \& Menezes, D. (2001). Applications of multivariate analysis in international tourism research: The marketing strategy perspective of NTOs". Journal of Economic and Social Research, 3(1), 77-98.

Chen, J. S. (1998). The tourists' cognitive decision making model. The Tourist Review, 53(1), 4-9. DOI:10.1108/eb058263

Compton, J. (2016). "Image prepare: Image repair, Inoculation Theory, and anticipated attacks on credibility. International Journal of the Image, 8(1), 19.

Compton, J., \& Ivanov, B. (2013). Vaccinating voters: Surveying political campaign inoculation scholarship. Annals of the International Communication Association, 37(1), 251-283.

Compton, J., \& Pfau, M. (2004). Use of inoculation to foster resistance to credit card marketing targeting college students. Journal of Applied Communication Research, 32(4), 343-364.

Compton, J., \& Pfau, M. (2009). Spreading inoculation: Inoculation, resistance to influence, and word-of-mouth communication. Communication Theory, 19(1), 9-28.

Dalkey, N., \& Helmer, O. (1963). An experimental application of the delphi method to the use of experts. Management Science, 9(3), 458-467. DOI: 10.1287/mnsc.9.3.458

Edgell, D. L., Ruf, K. M., \& Agarwal, A. (2000). Strategic marketing planning for the tourism industry. Journal of Travel ve Tourism Marketing, 8(3), 111-120. DOI: 10.1300/J073v08n03 08 
Edgell, D. L. (2006). Marketing the sustainable tourism: A legacy for the future. Oxon: Routledge.

Emekli, G. (2003). "The place of Pergamon and Ephesus in the cultural tourism of Izmir". Aegean Geographical Journal, 12(1), 39-50.

Fiedler, K. (1991). "On the Task, the Measures and the Mood In Research on Affect and Social Cognition". In J. P. Forgas (Ed.), Emotion and social judgments (p. 22). Great Britain: BPCC Wheatons Ltd.

Forgas, J. P. (1994). The role of emotion in social judgments: An introductory review and an Affect Infusion Model (AIM). European Journal of Social Psychology, 24(1), 1-24.

Gilbert, D. (1990). "Strategic Marketing Planning for National Tourism". The Tourist Review, 45(1), 18-

\section{DOI:10.1108/eb058038}

Godbold, L. C., \& Pfau, M. (2000, August). Conferring resistance to peer pressure among adolescents: Using Inoculation Theory to discourage alcohol use. Communication Research, 27(4), 411437. DOI:10.1177/009365000027004001

Golden, L. L., \& Alpert, M. I. (1987). Comparative analysis of the relative effectiveness of one-and twosided communication for contrasting products". Journal of Advertising, 16(1), 18-68.

Haigh, M. M., \& Pfau, M. (2006). Bolstering organizational identity, commitment, and citizenship behaviors through the process of inoculation. International Journal of Organizational Analysis, 14(4), 295-316.

Hagtvedt, H., \& Patrick, V. M. (2008). Art infusion: The influence of visual art on the perception and evaluation of consumer products. Journal of Marketing Research, 45(3), 379-389.

Heath, E. \& Wall, G. (1991). Marketing tourism destinations: A strategic planning approach. New York: John Wiley ve Sons, Inc.

Hovland, C. I., Lumsdaine, A. A., \& Sheffield, F. D. (1949). Experiments on mass communication. (Studies in Social Psychology in World War II), Vol. 3. Princeton: Princeton University Press.

Ivanov, B., Parker, K. A., \& Compton, J. (2011). The potential of inoculation in reducing post-purchase dissonance: Reinforcement of purchase behavior. Central Business Review, 30, 10-16.
Ivanov, B., Parker, K. A., Miller, C. H., \& Pfau, M. (2012). Culture as a moderator of Inoculation success: The effectiveness of a mainstream inoculation message on a subculture population". The Global Studies Journal, 4(3), 1-22.

Johnston, R. E.,\& Bate, J. D. (2013). The power of strategy innovation: A new way of linking creativity and strategic planning to discover great business opportunities. New York: Amacom.

Karasar, N. (2014). Bilimsel araştırma yöntemleri. Ankara: Nobel Yayıncılık.

Kim, K., Ko, E., \& Lee, Y. I. (2012). Art Infusion in fashion product: The influence of visual art on product evaluation and purchase intention of consumers. Journal of Global Fashion Marketing, 3(4), 180-186. DOI:10.1080/20932685.2012.10600848

Kunt, S. (2019). "The measuring of creative infusion via inoculation theory in the tangible cultural heritage destination marketing: A research on the Seven Churches" (Ph.D. Thesis). Ankara: Gazi University.

Kunt, S. \& Gülcan, B. (2017). Türkiye inanç turizminde zenginleşememiş bir ürün: Yedi Kiliseler. Journal of Recreation and Tourism Research, 4 (Special Issue I), 184-206.

Küçük, M.A. (2013). İnanç turizmi açısından Türkiye'de dini mekânlar (Yahudilik-Hıristiyanlık Örneği). Ankara: Berikan Yayınevi.

Lalone, M. B. (2005). An anthro-planning approach to local heritage tourism: Case studies from Appalachia. NAPA Bulletin, 23(1), 135-150.

Lessne, G. J., \& Didow, N. M. (1987). Inoculation Theory and resistance to persuasion in marketing. Psychology and Marketing, 4(2), 157-165. DOl:10.1002/mar.4220040208

Lin, W. K. (2005). Inoculation to resist attacks. Asian Journal of Communication, 15(1), 85102. DOI:10.1080/0129298042000329810

Lumsdaine, A. A., \& Janis, I. L. (1953). Resistance to 'counterpropaganda' produced by one-sided and two-sided 'propaganda' presentations. Public Opinion Quarterly, 17(3), 311-318.

Macharia, J. K., \& Pelser, T. G. (2014). Key factors that influence the diffusion and infusion of information and communication technologies in 
Kenyan higher education. Studies in Higher Education, 39(4), 695-709.

Metaxas, T. (2009). "Place marketing, strategic planning and competitiveness: The case of Malta". European Planning Studies, 17(9), 1357-1378.

Mikolon, S., Quaiser, B., \& Wieseke, J. (2015). "Don't try harder: Using customer inoculation to build resistance against service failures. Journal of the Academy of Marketing Science, 43(4), 512-527.

McGuire, W. J. (1961a). The effectiveness of supportive and refutational defenses in immunizing and restoring beliefs against persuasion. Sociometry, 24(2), 184-197.

McGuire, W. J. (1961b). Resistance to persuasion conferred by active and passive prior refutation of the same and alternative counterarguments. Journal of Abnormal and Social Psychology, 63, 326-332.

Mcguire, W.J. (1964). Inducing Resistance to Persuasion: Some Contemporary Approaches. In L. Berkowitz (Ed.), Advances in experimental social psychology (pp. 191-229). New York: Academic Press.

McGuire, W. J., \& Papageorgis, D. (1961). The relative efficacy of various types of prior beliefdefense in producing immunity against persuasion. The Journal of Abnormal and Social Psychology, 62(2), 327.

McGuire, W. J., \& Papageorgis, D. (1962). Effectiveness of forewarning in developing resistance to persuasion. Public Opinion Quarterly, 26(1), 24-34.

Mclntyre, R. P. (1993). An approach to fostering creativity in marketing. Marketing Education Review, 3(1), 33-36.

Muhcina, S., \& Liviu, B. (2012). Strategic marketing in tourism. Ovidius University Annals, Economic Sciences Series, 12(1), 1049-1051.

Öter, Z. \& Çetinkaya, M. Y. (2016). Interfaith tourist behaviour at religious heritage sites: House of the Virgin Mary case in Turkey. International Journal of Religious Tourismand Pilgrimage, 4(4), 1-18.

Özdemir, G. (2008). Destinasyon Pazarlaması. Ankara: Detay Yayıncılık.

Pfau, M., \& Burgoon, M. (1988). Inoculation in political campaign communication. Human Communication Research, 15(1), 91-111.
Pfau, M., Tusing, K. J., Koerner, A. F., Lee, W., Godbold, L. C., Penaloza, L. J., \& Hong, Y. H. (1997). Enriching the Inoculation Construct: The Role of Critical Components in the Process of Resistance. Human Communication Research, 24(2), 187-215.

Pfau, M., Haigh, M. M., Sims, J., \& Wigley, S. (2007). The influence of corporate front-group stealth campaigns". Communication Research, 34(1), 73-99.

Poria, Y., Butler, R., \& Airey, D. (2003). The core of heritage tourism. Annals of Tourism Research, 30(1), 238-254. DOI:10.1016/S0160-7383(02)00064-6

Ramsay, W. (1904). The Letters to the Seven Churches in Asia. New York: Armstrong.

Rovelstad, J. M. \& Blazer, S. R. (1983). Research and strategic marketing in tourism: A status report. Journal of Travel Research, 22(2), 2-7.

Slater, S. F., Hult, G. T. M., \& Olson, E. M. (2010). Factors influencing the relative importance of marketing strategy creativity and marketing strategy implementation effectiveness. Industrial Marketing Management, 39(4), 551-559.

Seven Churches Documentary (2014). The Ministry of Culture and Tourism, Ankara.

Soteriades, M. D. \& Avgeli, V. A. (2007). Promoting tourism destinations: A strategic marketing approach. Tourism Review, 55(3), 335-345.

Tsiotsou, R. H. \& Goldsmith, R. E. (2012). Introduction to strategic marketing in tourism". In R. H. Tsiotsou and R. E. Goldsmith (Eds.), Strategic marketing in tourism services. United Kingdom: Emerald Group Publishing.

The Bible (2010). İstanbul: Ohan Matbaacılık.

Thompson, D., Baranowski, T., Buday, R., Baranowski, J., Thompson, V., Jago, R., \& Griffith, M. J. (2010). Serious video games for health: How behavioral science guided the development of a serious video game. Simulation and Gaming, 41(4), 587-606.

Wan, H. H., \& Pfau, M. (2004). The relative effectiveness of inoculation, bolstering, and combined approaches in crisis communication. Journal of Public Relations Research, 16(3), 301-328. 
Potential impact of creative infusion on perceptions and behaviors of visitors: theory and evidence from tourism

Wickramasinghe, V. S. K., \& Takano, S. E. (2009). Application of combined SWOT and Analytic Hierarchy Process (AHP) for tourism revival strategic marketing planning: A case of Sri Lanka tourism. Journal of the Eastern Asia Society for Transportation Studies, 8, 954-969.

Wilson, M. (2010). Biblical Turkey. İzmir: Ege Yayınları.
Wilson, V. (2014). Research methods: triangulation. Evidence Based Library And Information Practice, 9(1), 74-75.

Wood M.D., Thorne S., Butte G. (2016). Technology Infusion and Marketing. In M.D. Wood, S. Thorne, D. Kovacs, G. Butte and I. Linkov (Eds.), Mental Modeling Approach: Risk Management Application Case Studies (pp.69-82). New York: Springer. DOI:10.1007/978-1-4939-6616-5_6 